Edullumaniora: Jurnal Pendidikan Dasar | ISSN 2085-1243

Vol. 8. No.2 Juli 2016 | Hal 107-125

\title{
STUDI ANALISIS KEBUTUHAN TERHADAP PENGEMBANGAN MODEL BLENDED LEARNING PADA SISTEM PENDIDIKAN JARAK JAUH UNTUK MENINGKATKAN KOMPETENSI LULUSAN Oleh: Dina Thaib ${ }^{1}$, Dinn Wahyudin, Yulia Rahmawati, Cepi Riyana
}

\begin{abstract}
Open University in Indonesia as the higher education institution is using DE modes. All course content are delivered through printed learning modules, and 25 percent of course materials are multimedia packages. Learning support is provided via face-to-face, online, and broadcast modes. Radio tutorials are broadcast by the government-owned National Radio Station Network. Online courses use a learning management system. All online support services can be accessed by students through the UT-Online portal, which contains online tutorials and exercises, Web-based learning materials, streamed TV programs, a digital library with journals and transcripts, academic counseling, and ther online education facilities. This study aimed to analyze the need of the development model of blended learning for action research course which increasing the competence of primary school teacher students. The research was conducted in UPPJJ UT Bandung, one of UT's regional office in west java. Research subject was students, tutors and administrator classroom. By the study, specific goals can be outlined as follows: (i) to study the existing condition of the learning process that occurs at present in S1 PGSD UPBJJ UT Bandung; (ii) to develop form of a blended learning model can improve the competency of graduates; (iii) to study the perceptions of students and faculty on the application of blended learning model on distance learning System; (iv) to study the effectiveness of blended learning model on distance learning systems at UPBJJ SI PGSD Bandung Indonesia.
\end{abstract}

Keyword: Long Distance Education, blended learning; teacher education

\begin{abstract}
Abstrak: Universitas Terbuka di Indonesia adalah lembaga pendidikan tinggi yang menggunakan DE mode. Seluruh perkuliahan disampaikan melalui modul pembelajaran cetak, dan 25 persen dari materi perkuliahan adalah paket multimedia. Dukungan belajar disediakan melalui tatap muka, online, dan mode broadcast. tutorial radio yang disiarkan oleh Jaringan Stasiun Radio Nasional milik pemerintah. Perkuliahan online menggunakan sistem manajemen pembelajaran. Semua layanan dukungan online dapat diakses oleh siswa melalui portal UT-Online, yang berisi tutorial online dan latihan, bahan belajar berbasis web, streaming program TV, perpustakaan digital dengan jurnal dan transkrip, konseling akademik, dan fasilitas pendidikan online. Penelitian ini bertujuan untuk menganalisis kebutuhan model pengembangan blended learning untuk perkuliahan penelitian tindakan yang meningkatkan kompetensi siswa guru sekolah dasar. Penelitian ini dilakukan di UPPJJ UT Bandung, salah satu kantor regional UT di Jawa Barat. Subjek penelitian ini adalah siswa, tutor dan administrator kelas. Pemelitian ini memiliki tujuan spesifik yang dapat diuraikan sebagai berikut: (i) untuk mempelajari kondisi yang ada dari proses pembelajaran yang terjadi saat ini di S1 PGSD UPBJJ UT Bandung; (ii) mengembangkan bentuk model blended learning dapat meningkatkan kompetensi lulusan; (iii) untuk mempelajari persepsi mahasiswa dan fakultas pada penerapan model pembelajaran blended tentang Sistem pembelajaran jarak jauh; (iv) untuk mempelajari efektivitas model pembelajaran blended pada sistem pembelajaran jarak jauh di UPBJJ S1 PGSD Bandung Indonesia..
\end{abstract}

Kata Kunci: pendidikan jarak jauh, blended learnng, pendidikan guru

\footnotetext{
${ }^{1}$ Universitas Terbuka
} 


\section{PENDAHULUAN}

Kebutuhan terhadap guru yang berkualitas terus diupayakan oleh para pengelola pendidikan guru. Ditunjukkan dengan senantiasa meningkatkan mutu program pendidikan yang ditawarkannya. Perbaikan mutu pendidikan pada jenjang pendidikan tinggi ini jelas akan membawa dampak positif bagi penciptaan guru yang berkualitas. Untuk menciptakan pendidikan guru yang berkualitas, merujuk pada hasil penelitian Darling-Hammond dan Bransford (2005) bahwa minimal terdapat tiga elemen penting dalam desain program pendidikan guru yang harus diperbaiki. Ketiga elemen tersebut yaitu konten pendidikan guru, proses pembelajaran, dan konteks pembelajaran. Dalam pendidikan guru, termasuk pendidikan guru melalui jarak jauh dan terbuka, penguasaan teori, metode, strategi pembelajaran yang mendidik yang dalam perkuliahan di kelas harus dikaitkan dan dipadukan dengan bagaimana peserta belajar di sekolah dengan segenap latar belakang sosial-kulturalnya.

Kebijakan pemerintah saat ini adalah bahwa semua guru pada tahun 2015 harus bergelar akademik sarjana strata 1 (S1) dan tidak ada lagi yang hanya tamatan Diploma II, bagi guru yang tamatan Diploma II akan ditolak menjadi guru kecuali di daerah-daerah terpencil, dengan catatan guru yang bersangkutan sedang menyelesaikan pendidikan S1. Di Indonesia masih banyak permasalahan guru yang saat ini jumlahnya 2.783.321 orang, termasuk sekitar 477.000 orang di antaranya adalah guru di bawah Departemen Agama. Guru-guru yang masih belum pendidikan $\mathrm{S} 1$ harus mengikuti program pendidikan kualifikasi ke S1 yang diselenggarakan oleh LPTK baik negeri maupun swasta yang memiliki program studi terakreditasi pada BAN-PT. Berdasarkan kebijakan tersebut, maka penyelenggaraan pendidikan bagi para pendidik terus ditingkatkan melalui berbagai bentuk dan jenis pendidikan, diantaranya semakin memperkuat pola pendidikan jarak jauh. Universitas Terbuka (UT) merupakan universitas yang menerapkan sistem pendidikan tinggi jarak jauh dan terbuka.

Namun demikian, masih ditemukan sejumlah permasalahan yang dihadapi dalam implementasi pendidikan jarak jauh di Indonesia dan negara lain di Asia Pasifik, seperti dikemukakan (Belawati, : 2003 dan Latchem et all : 2008 ) “... in addition to accessibility and cost problems, there are capability, technical support, regulatory, and political barriers These may take years to resolve in the least developed countries. For this reason, the Open University of Indonesia have prudently maintained traditional media alongside online methods".

Dalam konteks permasalahan di UT, persoalan yang masih dirasakan dalam pengelolaan pembelajaran di UT ada pada tutor dan mahasiswa, seperti yang diungkap dari hasil penelitian Purwanto (2009) bahwa keefektifan belajar mandiri mahasiswa program UT masih mengalami hambatan untuk belajar mandiri, mereka masih kesulitan untuk belajar secara mandiri dengan berbagai alasan, seperti keterbatasan waktu dan modul yang sulit untuk dipahami, sehingga masih diperlukan kegiatan tutorial untuk membantu mahasiswa didalam memahami materi yang terdapat pada modul. Persoalan empirik dirasakan oleh peneliti dalam posisi sebagai tutor. Masih terasa adanya berbagai kendala di dalam proses pembelajaran mata kuliah yang berbasis karya tulis ilmiah khususnya dalam mata kuliah Penelitian Tindakan Kelas (PTK) terutama dalam intensitas interaksi dalam proses bimbingan sehingga diperlukan medium lain untuk penguatan pengalaman belajar mahasiswa. Oleh karena itu pada penelitian ini penulis mencoba mengkaji hal-hal terkait pengembangan model 
Blended Learning dalam meningkatkan kompetensi lulusan pada Sistem Pembelajaran Jarak Jauh di Univesitas Terbuka.

\section{TINJUAN PUSTAKA}

Blended e-Learning merupakan isu pendidikan terbaru dalam perkembangan globalisasi dan teknologi e-learning. Zhao (2008:162) menjelaskan bahwa:

Blended e-Learning offers a new learning approach for combining different delivery modes, normally is online and face-to-face teaching to two remote sites by means of Blended $e$ Learning, a combination of face-to-face and distance learning

Pernyataan dari Zhao juga menekankan pendekatan pembelajaran terbaru tapi penyampaian pesan yang dikombinasikan melalui dua cara online dan mengajar tatap muka pada tempat yang berjauhan dengan cara blended e-learning, suatu kombinasi tatap muka dan pendidikan jarak jauh. Pada intinya menggabungkan dua pendekatan pembelajaran yang digunakan sehingga menjadi pendekatan pembelajaran baru. Selanjutnya blended learning telah didefinisikan dalam Cisco System (2001) adalah (Ahmed, 2008:18): as the combination of characteristic from both traditional learning and e-learning environments. It merges aspects of e-learning such as: web-based instruction, streaming video, audio synchronous and asynchrounous communication, etc; with traditional "face to face" learning.

Blended Learning sebagai kombinasi karakteristik pembelajaran tradisional dan lingkungan pembelajaran elektonik atau $e$ learning. menggabungkan aspek e-learning seperti pembelajaran berbasis web, streaming video, komunikasi audio synchronous, dan asynchronous dengan pembelajaran tradisional "tatap muka" Pendapat lainnya dipaparkan Bhonk dan Graham (2006) juga mendefinisikan sebagai berikut : blended learning is the combination of instruction from two historically separate models of teaching and learning: Traditional learning systems and distributed learning systems. It emphasizes the central role of computerbased technologies in blended learning." (Hadjerrouit, 2007: 286). Bhonk dan Graham (2006) menjelaskan bahwa blended learning adalah gabungan dari dua sejarah model perpisahan mengajar dan belajar: sistem pembelajaran tradisional dan sistem penyebaran pembelajaran, yang menekankan peran pusat teknologi berbasis komputer dalam blended learning.

Aspek yang dapat dikembangkan untuk meningkatkan kompetensi guru adalah melalui penguatan terhadap model Blended Learning, yakni model pembelajaran yang menggabungkan antara pembelajaran konvensional (face to face) dengan pembelajaran berbasis ICT. Daya dukung program ini adalah fasilitas ICT berupa web LMS, program tutor online, tutor kunjung, modular dan suplemen dalam bentuk multimedia.

Berdasarkan komponen yang ada dalam Blended e-Learning maka teori belajar yang mendasari model pembelajaran tersebut adalah teori belajar konstruktivisme (individual learning) dari Piaget, kognitif dari Bruner, Gagne dan Blooms dan lingkungan belajar sosial atau Social Constructivist (collaborative learning) dari Vygtsky. Konstruktivisme (indiviual learning) digunakan sebagai landasan teori belajar yang sering disebut juga student centered learning. Konstruktivisme (individual learning) dapat mendorong pelajar untuk membangun pengetahuan mereka sendiri berdasarkan pengalaman individu dan mengaplikasikannya secara langsung pada lingkungan mereka (Paurelle, 2003). 
Karakteristik teori belajar konstruktivisme (individual learning) untuk e-learning (Hasibuan, 2006:4) adalah : (1) Active learners, (2) Learners construct their knowledge, (3) Subjective, dynamic and expanding, (4) Processing and understanding of information, (5) Learner has his own learning, (6) Individual learning.

Pada teori ini pelajar adalah pesera yang aktif, kalau dapat membangun pengetahuan mereka sendiri, secara subjektif, dinamis dan berkembang. Kemudian memperoses dan memahami suatu informasi, sehingga pelajar memiliki pembelajarannya sendiri. Pelajar membangun pengetahuan mereka berdasarkan atas pengetahuan dari pengalaman yang mereka alami sendiri. Teori belajar berikutnya yang melandasi model Blended e-Learning adalah teori belajar kognitif. Pendekatan kognitif menekankan bagan sebagai satu struktur pengetahuan yang diorganisir (Bruner, 1990; Gagne et al, 1993). Menurut Bloom (1956) mengidentifikasi enam tingkatan belajar kognitif yaitu "pengetahuan, pemahaman, aplikasi, analisis dan sintesis". pandangan kognitif pada pembelajaran menunjukkan kegiatan mental, seperti pemberian alasan analisis dan pemikiran kritis (Hadjerrouit: 2007, Carman 2005:5).

Teori berikutnya adalah teori belajar konstruktivisme sosial yang dikembangkan oleh Vygotsky. Menurut Vygotsky (1978) adalah sebagai berikut: the way learners construct knowledge, think, reason, and reflect on is uniquely shaped by their relationships with others. He argued that the guidance given by more capable others, allows the learner to engage in levels of activity that could not be managed alone. Konstruktivisme sosial disebut juga collaborative learning.

\section{METODOLOGI PENELITIAN}

Langkah penelitian ini mengacu pada Brog dan Gall serta penyederhanaan kerangka operasional dari Sukmadinata, (2005:189). Penelitian ini dilakukan dalam 3 tahap, yaitu Tahap1 Studi Analisis/Pendahuluan; Tahap 2 Pengembangan model, dan Tahap 3 Validasi model.

Tahap 1 : Studi Analisis/Pendahuluan, Kegiatan pendahuluan adalah kegiatan prapenelitian yang bertujuan untuk mengumpulkan data-data awal serta menyiapkan kerangka konseptual dari tema penelitian. Atas dasar hal tersebut, pada tahap studi pendahuluan, peneliti melakukan dua kegiatan utama, yaitu (1) Studi literatur, dan (2) survey pendahuluan. Pada tahap survey pendahuluan, dilakukan observasi sistem pembelajaran yang terjadi di UT saat ini. Survey bertujuan untuk : mengungkap kurikulum yang digunakan, kesesuaiannya dengan standar kompetensi nasional yang berlaku, mengkaji model-model yang biasa digunakan oleh lembaga sejenis serta kemungkinan untuk bisa dikembangkan lebih lanjut. (Laporan Penelitian ini lebih merupakan laporan tahap 1).

Tahap 2 :Pengembangan dan Pengujian Model, pada tahap ini dilakukan kegiatan penyusunan draf awal model, kemudian dilakukan uji coba secara terbatas, dan selanjutnya dilakukan uji coba lebih luas. Kedua kegiatan uji coba tersebut dilakukan dalam rangka menghasilkan desain model final yang siap untuk divalidasi. (dilaksanakan tahun 2).

\section{HASIL PENELITIAN DAN PEMBAHASAN}

\section{Kondisi Proses Pembelajaran Saat Ini Mata Pelajaran PTK}

PTK merupakan salah satu mata kuliah wajib yang harus ditempuh mahasiswa UT dalam program S1 Pendidikan Dasar (PGSD). Mata kuliah ini membahas tentang hakikat Penelitian Tindakan Kelas (PTK), 
menyusun dan menggunakan instrumen penelitian serta merekam hasilnya, merancang dan melaksanakan PTK, menganalisis, menerjemahkan hasil analisis data dan memanfaatkan temuan PTK serta menulis laporan hasil PTK. Mata Kuliah PTK sudah berlangsung lama di UT dengan menggunakan pola tutorial yang dilengkapi dengan modul. a. Kondisi Perencanaan Pembelajaran pada Tutorial PTK saat ini

Perencanaan pembelajaran pada pelaksanaan tutorial di UT menggunakan terminologi Satuan Acara Tutorial (SAT) dan Rencana Aktivitas Tutorial (RAT). Penelitian ini mencoba menggali data sejauh mana mahasiswa mengetahui adanya perencanaan pembelajaran di UT, berikut data yang dapat diperoleh:

Tabel-1

Pengetahuan Mahasiswa tentang Perencanaan Pembelajaran

\begin{tabular}{|l|c|c|}
\hline Indikator & Ya (\%) & tidak \\
\hline Satuan Acara Tutorial (SAT) & 30.5 & 69.5 \\
Rancangan Aktivitas Tutorial (RAT) & 36.1 & 65.9 \\
Silabus & 27.8 & 72.2 \\
Handout/Modl/Buku & 88.5 & 21.5 \\
Media Pembelajaran & 30.6 & 69.4 \\
\hline
\end{tabular}

Dari data tersebut dapat ditafsirkan bahwa perencanaan pembelajaran yang diketahui oleh mahasiswa lebih didominasi oleh Modul sebanyak $88 \%$ dan mahasiswa tidak banyak yang mengetahui tentang perencanaan pembelajaran berupa Satuan Acara Tutorial (SAT) dan Rencana Aktivitas
Tutorial (RAT) yakni hanya 30,5\% saja yang mengatakan mengetahui. Hal ini karena tutor jarang menginformasikan adanya SAT dan RAT kepada mahasiswa. Informasi tentang SAT dan RAT yang diketahui oleh siswa sumber informasinya lebih banyak bersumber dari Tutor, yaitu $69,4 \%$.

Tabel-2

Sumber Informasi kelengkapan Perkuliahan PTK

\begin{tabular}{|l|l|l|}
\hline Sumber Informasi & Frequensy & persen \\
\hline Dari Tutor & 25 & 69.4 \\
Dari Mahasiswa Tingkat Atas & & \\
Dari Pengelola & 10 & 27.7 \\
Dari hasil Pencarian di Internet & 1 & 2.9 \\
\hline
\end{tabular}

b. Sistem pengembangan bahan ajar pada Sistem Pembelajaran Jarak Jauh yang digunakan saat ini pada program S1 PGSD UPBJJ UT Bandung

Pola pembelajaran jarak jauh yang diterapkan UT menjadikan bahan ajar (learning materials) menjadi sangat penting, karena belajar siswa lebih banyak mengandalkan bahan ajar mengingat tatap muka pembelajaran lebih sedikit dibandingkan dengan belajar mandiri. Oleh karena itu siswa membutuhkan bahan ajar untuk memandu proses pembelajarannya. Peneliti menggali data bagaimana sistem pengembangan bahan ajar pada program S1 PGSD UPBJJ UT Bandung. Berikut beberapa data yang digali dari Tutor dan mahaiswa. 
Tabel-3

Fasilitas Bahan Ajar Ketika perkuliahan PTK

\begin{tabular}{|c|c|c|c|c|}
\hline & Frequency & Percent & $\begin{array}{l}\text { Valid } \\
\text { Percent }\end{array}$ & Cumulative Percent \\
\hline Cukup & 7 & 19.4 & 19.4 & 19.4 \\
\hline Baik & 17 & 47.2 & 47.2 & 66.7 \\
\hline sangat baik & 12 & 33.3 & 33.3 & 100.0 \\
\hline Total & 36 & 100.0 & 100.0 & \\
\hline
\end{tabular}

Dari tabel tersebut dapat ditafsirkan bahwa bahan ajar berupa Modul Cetak dan Modul Elektronik di beberapa mata kuliah memperoleh penilaian "Baik" dari mahasiswa sebanyak $47,2 \%$, sedangkan yang mengatakan "Cukup Baik" sebanyak $19,4 \%$. Hal ini menunjukkan bahwa modul PTK yang selama ini digunakan mahasiswa yang sudah disiapkan dan dikembangkan oleh UT sudah baik dan sesuai dengan kriteria dan persepsi mahasiswa. Pendapat mahasiswa tersebut sejalan dengan pendapat tutor sebanyak $80 \%$ Tutor menyatakan kondisi baik utuk fasilitas belajar.

\section{c. Metode pembelajaran yang digunakan}

Proses pembelajaran tidak terlepas dari penggunaan metode dan teknik pembelajaran yang mengelola mahasiswa untuk berperan aktif dalam pembelajaran. Peneliti menggali data dalam pelaksanaan tutorial, sejauh mana para tutor menggunakan pola tutorial serta gambaran aktivitas mahasiswa selama proses tutorial berlangsung. Diperoleh gambaran sebagai berikut.

\section{Tabel-4}

\section{Kemandirian Belajar}

\begin{tabular}{|c|c|c|c|}
\hline Frequency & Percent & Valid Percent & Cumulative Percent \\
\hline 8 & 22.2 & 22.2 & 22.2 \\
23 & 63.9 & 63.9 & 86.1 \\
5 & 13.9 & 13.9 & 100.0 \\
36 & 100.0 & 100.0 & \\
\hline
\end{tabular}

Dari tabel tersebut dapat dijelaskan bahwa program tutorial untuk Mata Kuliah PTK memberikan dampak terhadap kemandirian belajar mahasiswa. Hal tersebut diperkuat oleh pengakuan mahasiswa yang menyatakan kemandiriannya dalam belajar berkategori "Baik" sebanyak 63,9\%. Selain itu, penggunaan metode tutorial menuntut mahasiswa untuk bekerjasama dalam menyelesaikan setiap tugas-tugas yang diberikan oleh tutor atau pembelajaran kooperatif disetiap pembahasan topik perkuliahan. 
Tabel-5

Kemauan Bekerjasama dalam Tutorial

\begin{tabular}{|rl|r|r|r|r|}
\hline & Frequency & Percent & \multicolumn{1}{l|}{$\begin{array}{l}\text { Valid } \\
\text { Percent }\end{array}$} & \multicolumn{1}{l|}{ Cumulative Percent } \\
\hline \multirow{2}{*}{ Valid } & cukup & 9 & 25.0 & 25.0 & 25.0 \\
& Baik & 21 & 58.3 & 58.3 & 83.3 \\
& sangat baik & 6 & 16.7 & 16.7 & 100.0 \\
& Total & 36 & 100.0 & 100.0 & \\
\hline
\end{tabular}

Kemampuan untuk bekerjasama terbukti secara statistik pada tabel di atas, terdapat 21 orang dari total 36 responden yang menyatakan "Baik" untuk kemauan bekerjasama, atau sebesar 58\%. Hal ini memperkuat untuk digunakannya metode tutorial karena memberikan efek terhadap kemauan dan kemampuan mahasiswa untuk bekerjasama.

\section{d. Fasilitas pembelajaran pada Sistem Pembelajaran Jarak Jauh}

Keberadaan fasilitas memberikan pengaruh yang besar terhadap keberhasilan pembelajaran, begitu juga dalam kegiatan tutorial. Meskipun bukan merupakan pembelajaran yang biasa (reguler), penggunaan fasilitas belajar menjadi aspek yang perlu diperhatikan. Peneliti berusaha menggali data kondisi fasilitas pembelajaran dalam kegiatan tutorial yang ada saat ini.

\section{1). Kondisi Ruang Belajar Tutorial PTK saat ini}

Tabel-6

Fasilitas Ruang Belajar PadaTutorial PTK

\begin{tabular}{|l|r|r|r|r|}
\hline & Frequency & Percent & \multicolumn{1}{|l|}{$\begin{array}{l}\text { Valid } \\
\text { Percent }\end{array}$} & Cumulative Percent \\
\hline Buruk & 7 & 19.4 & 19.4 & 19.4 \\
Cukup & 13 & 36.1 & 36.1 & 55.6 \\
Valid Baik & 15 & 41.7 & 41.7 & 97.2 \\
Sangat Baik & 1 & 2.8 & 2.8 & 100.0 \\
Total & 36 & 100.0 & 100.0 & \\
\hline
\end{tabular}

Fasilitas belajar berupa ruang belajar pada umumnya mahasiswa menyatakan baik, yakni $41,7 \%$ dan cukup baik sebanyak $36,1 \%$. Berbeda dengan mahasiswa, para tutor menilai bahwa fasilitas ruang belajar pada umumnya cukup, yakni sebanyak $80 \%$ sedang yang mengatakan baik dan sangat baik hanya $10 \%$. 
Tabel-7

Fasilitas Ruang Belajar Ketika perkuliahan PTK

\begin{tabular}{|ll|l|l|l|l|}
\hline & Frequency & Percent & $\begin{array}{l}\text { Valid } \\
\text { Percent }\end{array}$ & Cumulative Percent \\
\hline \multirow{2}{*}{ Valid } & Cukup & 8 & 80.0 & 80.0 & 80.0 \\
& Baik & 1 & 10.0 & 10.0 & 90.0 \\
& Sangat Baik & 1 & 10.0 & 10.0 & 100.0 \\
& Total & 10 & 100.0 & 100.0 & \\
\hline
\end{tabular}

2). Kondisi Fasilitas Laboratorium

Pada umumnya kondisi fasilitas laboratorium cukup baik, hal tersebut diakui oleh sebanyak $36.1 \%$ mahasiswa dan $27,8 \%$ kondisinya buruk yang perlu peningkatan lebih lanjut.

Tabel-8

Kondisi Fasilitas Laboratorium

\begin{tabular}{|c|c|c|c|c|c|}
\hline & & Frequency & Percent & Valid Percent & $\begin{array}{l}\text { Cumulative } \\
\text { Percent }\end{array}$ \\
\hline \multirow{6}{*}{ Valid } & Sangat Buruk & 6 & 16.7 & 16.7 & 16.7 \\
\hline & Buruk & 10 & 27.8 & 27.8 & 44.4 \\
\hline & Cukup & 13 & 36.1 & 36.1 & 80.6 \\
\hline & Baik & 6 & 16.7 & 16.7 & 97.2 \\
\hline & Sangat Baik & 1 & 2.8 & 2.8 & 100.0 \\
\hline & Total & 36 & 100.0 & 100.0 & \\
\hline
\end{tabular}

e

- Pemahaman mahasiswa terhadap Mata Kuliah PTK

Pemahaman atau daya serap terhadap materi yang dipelajari menjadi indikator utama keberhasilan pembelajaran. Mata Kuliah PTK sebagai bidang kajian yang penting sebagai kompetensi pedagogik guru perlu dikaji secara mendalam bagaimana capaiannya dalam pembelajaran. Berikut beberapa data yang berhasil digali dari mahasiswa terhadap daya serapnya pada Mata Kuliah PTK.

Tabel-9

Kondisi Daya Serap menganalisis dan merumuskan masalah

\begin{tabular}{|ll|r|c|c|c|}
\hline & Frequency & Percent & $\begin{array}{c}\text { Valid } \\
\text { Percent }\end{array}$ & Cumulative Percent \\
\hline \multirow{2}{*}{ Valid } & cukup & 17 & 47.2 & 47.2 & 47.2 \\
& baik & 15 & 41.7 & 41.7 & 88.9 \\
& sangat baik & 4 & 11.1 & 11.1 & 100.0 \\
& Total & 36 & 100.0 & 100.0 & \\
\hline
\end{tabular}


Dari tabel tersebut dapat ditafsirkan bahwa daya serap mahasiswa terhadap kemampuan menganalisis masalah dan merumuskan masalah dalam PTK masih berkategori "Cukup Baik" yakni diakui mahasiswa sebanyak $47,2 \%$ dan hanya
$41,7 \%$ saja yang menyatakan 'Baik". Pendapat Tutor terhadap daya serap mahasiswa dalam merumuskan masalah malah sedikit lebih tinggi, yakni sebanyak $50 \%$ menyatakan "Baik".

Tabel-10

Kondisi Daya Serap Mahasiswa dalam Membuat Instrumen

\begin{tabular}{|c|c|c|c|c|c|}
\hline & & Frequency & Percent & $\begin{array}{c}\text { Valid } \\
\text { Percent }\end{array}$ & $\begin{array}{c}\text { Cumulative } \\
\text { Percent }\end{array}$ \\
\hline Valid & $\begin{array}{c}\text { cukup } \\
\text { baik } \\
\text { sangat baik } \\
\text { Total }\end{array}$ & $\begin{array}{l}16 \\
18 \\
2 \\
36\end{array}$ & $\begin{array}{c}44.4 \\
50.0 \\
5.6 \\
100.0\end{array}$ & $\begin{array}{c}44.4 \\
50.0 \\
5.6 \\
100.0\end{array}$ & $\begin{array}{l}44.4 \\
94.4 \\
100.0\end{array}$ \\
\hline
\end{tabular}

Setengah dari jumlah mahasiswa (50\%) menyatakan memiliki kemampuan yang baik dalam membuat instrumen penelitian. Sedangkan 44,4\% mengakui kemampuan dalam membuat instrumen cukup baik. Jika dilihat dari pendapat Tutor, data tersebut mengalami penurunan, karena hanya $40 \%$ saja mahasiswa yang memiliki kemampuan membuat instrumennya yang baik.

Tabel-11

Kondisi Daya Serap Mahasiswa dalam Membuat Instrumen menurut Tutor

\begin{tabular}{|c|c|c|c|c|c|}
\hline & & Frequency & Percent & $\begin{array}{l}\text { Valid } \\
\text { Percent }\end{array}$ & Cumulative Percent \\
\hline \multirow{4}{*}{ Valid } & buruk & 2 & 20.0 & 20.0 & 20.0 \\
\hline & cukup & 4 & 40.0 & 40.0 & 60.0 \\
\hline & baik & 4 & 40.0 & 40.0 & 100.0 \\
\hline & Total & 10 & 100.0 & 100.0 & \\
\hline
\end{tabular}

Tahapan dalam PTK yang lainnya adalah kemampuan untuk mengambil data dan menganalisis data tersebut menjadi informasi yang memiliki makna. Perihal kemampuan tersebut, diakui oleh mahasiswa lebih dari setengahnya yakni $58,3 \%$ baik, $30,6 \%$ cukup baik dan hanya $2,8 \%$ yang menyatakan buruk. 
Tabel-12

Pelaksanaan PTK

\begin{tabular}{|ll|r|r|r|r|}
\hline & Frequency & Percent & Valid Percent & \multicolumn{2}{l|}{$\begin{array}{l}\text { Pumulative } \\
\text { Percent }\end{array}$} \\
\hline \multirow{2}{*}{ Valid } & Cukup & 13 & 36.1 & 36.1 & 36.1 \\
& Baik & 16 & 44.4 & 44.4 & 80.6 \\
& sangat baik & 7 & 19.4 & 19.4 & 100.0 \\
& Total & 36 & 100.0 & 100.0 & \\
\hline
\end{tabular}

Kemampuan dalam melaksanakan PTK pada umumnya baik, yakni $44,4 \%$ dan sangat baik 19,4\%. Bagian akhir dari kemampuan mahasiswa dalam melakukan PTK adalah kemampuan membuat laporan PTK. Terhadap kemampuan tersebut kurang dari setengahnya 47,2\% menyatakan baik, disusul dengan 38,9\% berkemampuan cukup dalam membuat pelaporan.
2. Respon Mahasiswa Dan Tutor Terhadap Penerapan Blended Learning Pada Mata Kuliah PTK

Pada bagian ini peneliti menggali data tentang respon mahasiswa dan Tutor terhadap kemungkinan penggunaan Model Blended Learning dalam perkuliahan Penelitian Tindakan Kelas (PTK). Dari responden mahasiswa dan Tutor dapat diperoleh gambaran data sebagai berikut :

Tabel-13

Respon Mahasiswa tentang Sistem Tutorial

\begin{tabular}{|c|c|c|c|c|c|}
\hline & & Frequency & Percent & Valid Percent & $\begin{array}{c}\text { Cumulative } \\
\text { Percent }\end{array}$ \\
\hline \multirow{6}{*}{ Valid } & Tidak Perlu & 1 & 2.8 & 2.8 & 2.8 \\
\hline & rengayada & & & & \\
\hline & Masih perlu & 25 & 694 & 69.4 & 72.2 \\
\hline & Pengayaan & & & & \\
\hline & Sudah Cukup & 10 & 27.8 & 27.8 & 100.0 \\
\hline & Total & 36 & 100.0 & 100.0 & \\
\hline
\end{tabular}

Data tersebut menunjukkan bahwa perkuliahan PTK dengan menggunakan pola tutorial masih diperlukan adanya pengayaan.
Hal tersebut diakui oleh lebih dari setengahnya $(69,4 \%)$ mahasiswa menyatakan masih perlunya pengayaan. 
Tabel-14

Pendapat Mahasiswa terhadap Pola dan Bobot Pembelajaran PTK

\begin{tabular}{|l|r|r|r|r|}
\hline & Frequency & Percent & $\begin{array}{l}\text { Valid } \\
\text { Percent }\end{array}$ & $\begin{array}{l}\text { Cumulative } \\
\text { Percent }\end{array}$ \\
\hline $\begin{array}{l}\text { Lebih banyak teori di } \\
\text { bandingkan praktek } \\
\text { Seimbang antara teori dan } \\
\text { praktek }\end{array}$ & 11 & 19.4 & 19.4 & 19.4 \\
Valid $\begin{array}{l}\text { lebih banyak praktek } \\
\text { penyusunan dan pelaksanaa }\end{array}$ & 18 & 30.6 & 30.6 & 50.0 \\
& 36 & 50.0 & 50.0 & 100.0 \\
\hline
\end{tabular}

Tabel tersebut menjelaskan bahwa mahasiswa mengharapkan bahwa perkuliahan tutorial PTK lebih banyak praktek penyusunan dan pelaksanaan PTK.

Tabel-15

Pengetahuan Mahasiswa tentang Blended Learning

\begin{tabular}{|l|r|r|r|r|}
\hline & Frequency & Percent & $\begin{array}{l}\text { Valid } \\
\text { Percent }\end{array}$ & $\begin{array}{l}\text { Cumulative } \\
\text { Percent }\end{array}$ \\
\hline \multicolumn{1}{|l|}{$\begin{array}{l}\text { Tidak tahu Sama } \\
\text { sekali }\end{array}$} & 12 & 33.3 & 33.3 & 33.3 \\
Tahu tapi tidak & 15 & 41.7 & 41.7 & 75.0 \\
Malid & 9 & 25.0 & 25.0 & 100.0 \\
cukup mengetahui & 36 & 100.0 & 100.0 & \\
Total & & & \\
\hline
\end{tabular}

Blended Learning sebagai alternatif pola pembelajaran yang menggunakan perangkat ICT khususnya internet, belum dipahami secara mendalam oleh mahasiswa. Secara umum terdapat $41,7 \%$ mahasiswa menyatakan tahu tentang blended learning namun belum mendalami. Dan terdapat
Hal tersebut dinyatakan oleh setengah dari responden menyatakan ingin "lebih banyak praktek penyusunan dan pelaksanaan".

$33,3 \%$ mahasiswa yang sama sekali tidak mengetahui. Kondisi ini tidak terlalu perlu dipermasalahkan karena dalam hal ini mahasiswa sebagai peserta dalam pembelajaran yang lebih berperan sebagai pembelajar dibandingkan sebagai pengajar. 
Tabel-16

Skala Sikap Mahasiswa Mengenai Tutorial Online Tutorial dengan System Blended Learning

\begin{tabular}{|c|c|c|c|c|c|}
\hline \multirow[t]{2}{*}{ Pernyataan } & \multicolumn{5}{|c|}{$\%$} \\
\hline & SS & $\mathbf{S}$ & $\mathbf{R}$ & TS & STS \\
\hline $\begin{array}{l}\text { 1.Tutorial PTK dilengkapi dengan perangkat } \\
\text { pembelajaran berbasis internet (online learning) } \\
\text { sebagai sarana belajar mandiri mahasiswa }\end{array}$ & 16.7 & 69.4 & 5.6 & 2.8 & 5.6 \\
\hline $\begin{array}{l}\text { 2. Tutor menyediakan inisiasi (tugas) yang harus } \\
\text { dikerjakan oleh mahasiswa secara mandiri diluar } \\
\text { tatap muka melalui web e-learning dan mahasiswa } \\
\text { mengirimkan tugas tersebut melalui web }\end{array}$ & 11.1 & 52.8 & 19.4 & 13.9 & 2.8 \\
\hline $\begin{array}{l}\text { 3.Tutor dapat memeriksa tugas mahasiswa secara } \\
\text { lebih bebas waktu, dan lebih intensif dengan } \\
\text { pemanfaatan e-learning }\end{array}$ & 22.2 & 52.8 & 19.4 & 5.6 & 0 \\
\hline $\begin{array}{l}\text { 4.Aktifitas dan kehadiran mahasiswa dalam } \\
\text { menggunakan web dapat di deteksi frekwensi dan } \\
\text { keaktipannya sebagai bagian dari bahan penilaian }\end{array}$ & 2.8 & 77.8 & 11.1 & 8.3 & 0 \\
\hline $\begin{array}{l}\text { 5.Modul PTK yang ada sekarang perlu dilengkapi } \\
\text { dengan bahan tambahan (supplementary reading } \\
\text { yang lebih praktis dan mudah dicerna }\end{array}$ & 30.6 & 58.3 & 11.1 & 0 & 0 \\
\hline $\begin{array}{l}\text { 6.Bahan ajar cetak PTK perlu dilengkapi dengan } \\
\text { bahan ajar non cetak berupa video yang } \\
\text { menggambarkan pelaksanaan PTK }\end{array}$ & 38.9 & 55.6 & 2.8 & 0 & 2.8 \\
\hline $\begin{array}{l}\text { 7.Laporan PTK mahasiswa perlu dikirimkan soft } \\
\text { copy melalui web sebagai tugas akhir dan } \\
\text { memudahkan tutor pengelola untuk mendeteksi } \\
\text { orisinalitasnya melalui software plagiarisme }\end{array}$ & 8.3 & 55.6 & 27.8 & 5.6 & 2.8 \\
\hline $\begin{array}{l}\text { 8.Tugas akhir mahasiswa sebaiknya di kemas juga } \\
\text { dalam bentuk E-TA (elektronik tugas akhir yang } \\
\text { dapat dikemas melalui power point }\end{array}$ & 2.9 & 40.0 & 40.0 & 17.1 & \\
\hline $\begin{array}{l}\text { 9.Melalui integrasi tutorial tatap muka dan online } \\
\text { membuat pembelajaran PTK lebih berkualitas }\end{array}$ & 19.4 & 58.3 & 13.9 & 5.6 & 2.8 \\
\hline $\begin{array}{l}\text { 10. Dengan pemanfaatan internet dalam } \\
\text { pembelajaran TIK memudahkan mahasiswa dalam } \\
\text { pencairan sumber di internet terutama untuk kajian } \\
\text { teori }\end{array}$ & 11.1 & 55.6 & 27.8 & 5.6 & \\
\hline $\begin{array}{l}\text { 11. Melalui model Blended Learning } \\
\text { memberikan dampak pengiring (nurturant effect) } \\
\text { yaitu mahasiswa akan melek dalam penggunaan } \\
\text { ICT khususnya internet }\end{array}$ & 22.2 & 63.9 & 13.9 & & \\
\hline $\begin{array}{l}\text { 12. Penerapan Model Blended Learning dalam } \\
\text { PTK perlu sosialisasi dan pelatihan bagi } \\
\text { mahasiswa, tutor dan pengelola }\end{array}$ & 2.8 & 25 & 13.9 & 58.3 & \\
\hline $\begin{array}{l}\text { 13. Dengan adanya keterlibatan internet (e- } \\
\text { learning) maka frekwensi tatap muka langsung } \\
\text { antara Tutor dan mahasiswa perlu dikurangi }\end{array}$ & 11.1 & 80.6 & 2.8 & 2.8 & 2.8 \\
\hline $\begin{array}{l}\text { 14. Perlunya pedoman ringkas yang } \\
\text { menggambarkan teknis operasional implementasi } \\
\text { Blended Learning pada mata kuliah PTK untuk } \\
\text { memudahkan pemahaman }\end{array}$ & 11.1 & 80.6 & 2.8 & 2.8 & 2.8 \\
\hline $\begin{array}{l}\text { 15. Pemanfaatan ICT dalam pembelajaran PTK } \\
\text { dapat menghindari upaya mehasiswa dalam } \\
\text { menduplikasi laporan tanpa aturan yang benar }\end{array}$ & 2.8 & 72.2 & 13.9 & 11.1 & \\
\hline
\end{tabular}


Dari data pada tabel di atas dapat diambil rata-rata dari semua responden yang menyatakan setuju yakni sebesar 59,9\%. Ini mengandung arti bahwa mahasiswa menganggap perlunya terhadap semua pernyataan yang ditanyakan. tentang tutorial PTK.

Tabel-17

Pengetahuan tutor tentang model blended learning

\begin{tabular}{|c|c|c|c|c|}
\hline & Frequency & Percent & Valid Percent & $\begin{array}{c}\text { Cumulative } \\
\text { Percent }\end{array}$ \\
\hline Mengetahui banyak & 2 & 20 & & \\
Cukup mengetahui & 4 & 40 & & \\
Tahu tapi tidak & 4 & 40 & & \\
Valid $\quad$ mendalami & & & & \\
Tidak tahu sama & & & & \\
sekali & & & & \\
\hline
\end{tabular}

Secara umum terdapat $40 \%$ Tutor menyatakan tahu tentang blended learning namun belum mendalami. Dan terdapat $49 \%$ Tutor yang cukup mengetahui. Kondisi ini perlu diperhatikan karena dalam hal ini Tutor sebagai pelaku dalam pembelajaran yang lebih berperan sebagai pengatur pembelajaran dibandingkan penyampai materi saja. 
Tabel-18

Skala Sikap Pendapat Tutor Mengenai Tutorial Online

\begin{tabular}{|c|c|c|c|c|c|}
\hline \multirow{2}{*}{ Pernyataan } & \multicolumn{5}{|c|}{$\%$} \\
\hline & SS & $S$ & $\mathbf{R}$ & \begin{tabular}{|l|} 
TS \\
\end{tabular} & STS \\
\hline $\begin{array}{l}\text { 1. Tutorial PTK dilengkapi dengan perangkat } \\
\text { pembelajaran berbasis internet (online learning) } \\
\text { sebagai sarana belajar mandiri mahasiswa }\end{array}$ & 30 & 60 & 10 & 0 & 0 \\
\hline $\begin{array}{l}\text { 2. Tutor menyediakan inisiasi (tugas) yang harus } \\
\text { dikerjakan oleh mahasiswa secara mandiri diluar tatap } \\
\text { muka melalui web e-learning dan mahasiswa } \\
\text { mengirimkan tugas tersebut melalui web }\end{array}$ & 10 & 70 & 10 & 10 & 0 \\
\hline $\begin{array}{l}\text { 3. Tutor dapat memeriksa tugas mahasiswa secara } \\
\text { lebih bebas waktu, dan lebih intensif dengan } \\
\text { pemanfaatan e-learning }\end{array}$ & 20 & 70 & 0 & 10 & 0 \\
\hline $\begin{array}{l}\text { 4. Aktifitas dan kehadiran mahasiswa dalam } \\
\text { menggunakan web dapat di deteksi frekwensi dan } \\
\text { keaktipannya sebagai bagian dari bahan penilaian }\end{array}$ & 10 & 50 & 30 & 10 & 0 \\
\hline $\begin{array}{l}\text { 5. Modul PTK yang ada sekarang perlu dilengkapi } \\
\text { dengan bahan tambahan (supplementary reading yang } \\
\text { lebih praktis dan mudah dicerna }\end{array}$ & 20 & 70 & 0 & 10 & 0 \\
\hline $\begin{array}{l}\text { 6. Bahan ajar cetak PTK perlu dilengkapi dengan } \\
\text { bahan ajar non cetak berupa video yang } \\
\text { menggambarkan pelaksanaan PTK }\end{array}$ & 60 & 40 & 0 & 0 & 0 \\
\hline $\begin{array}{l}\text { 7. Laporan PTK mahasiswa perlu dikirimkan soft } \\
\text { copy melalui web sebagai tugas akhir dan } \\
\text { memudahkan tutor pengelola untuk mendeteksi } \\
\text { orisinalitasnya melalui software plagiarisme }\end{array}$ & 20 & 70 & 10 & 0 & 0 \\
\hline $\begin{array}{l}\text { 8. Tugas akhir mahasiswa sebaiknya di kemas } \\
\text { juga dalam bentuk E-TA (elektronik tugas akhir yang } \\
\text { dapat dikemas melalui power point }\end{array}$ & 10 & 90 & 0 & 0 & 0 \\
\hline $\begin{array}{l}\text { 9. Melalui integrasi tutorial tatap muka dan online } \\
\text { membuat pembelajaran PTK lebih berkualitas }\end{array}$ & 20 & 70 & 10 & 0 & 0 \\
\hline $\begin{array}{l}10 . \quad \text { Dengan pemanfaatan internet dalam } \\
\text { pembelajaran TIK memudahkan mahasiswa dalam } \\
\text { pencairan sumber di internet terutama untuk kajian } \\
\text { teori }\end{array}$ & 20 & 60 & 20 & 0 & 0 \\
\hline $\begin{array}{l}\text { 11. Melalui model Blended Learning memberikan } \\
\text { dampak pengiring (nurturant effect) yaitu mahasiswa } \\
\text { akan melek dalam penggunaan ICT khususnya internet }\end{array}$ & 30 & 70 & 0 & 0 & 0 \\
\hline $\begin{array}{l}\text { 12. Penerapan Model Blended Learning dalam PTK } \\
\text { perlu sosialisasi dan pelatihan bagi mahasiswa, tutor } \\
\text { dan pengelola }\end{array}$ & 40 & 60 & 0 & 0 & 0 \\
\hline $\begin{array}{l}\text { 13. Dengan adanya keterlibatan internet (e- } \\
\text { learning) maka frekwensi tatap muka langsung antara } \\
\text { Tutor dan mahasiswa perlu dikurangi }\end{array}$ & 20 & 30 & 30 & 20 & 0 \\
\hline $\begin{array}{l}\text { 14. Perlunya pedoman ringkas yang } \\
\text { menggambarkan teknis operasional implementasi } \\
\text { Blended Learning pada mata kuliah PTK untuk } \\
\text { memudahkan pemahaman }\end{array}$ & 10 & 50 & 10 & 30 & 0 \\
\hline $\begin{array}{l}\text { 15. Pemanfaatan ICT dalam pembelajaran PTK } \\
\text { dapat menghindari upaya mehasiswa dalam } \\
\text { menduplikasi laporan tanpa aturan yang benar }\end{array}$ & 10 & 90 & 0 & 0 & 0 \\
\hline
\end{tabular}


Dari data pada tabel di atas dapat diambil rata-rata dari semua responden (tutor) yang menyatakan setuju yakni sebesar $63,33 \%$. Ini mengandung arti bahwa Tutor menganggap

\section{Rancangan Model Blended Learning Pada Mata Kuliah PTK}

Kerangka Umum Model Pendidikan Jarak Jauh (PJJ), Indonesia sebagai negara yang luas dan merupakan kepulauan merupakan tantangan tersendiri untuk terwujudnya pemerataan (equity) dan peningkatan mutu pendidikan. Pendidikan perlunya tentang berbagai pernyataan yang ditanyakan tutorial online.

jarak jauh merupakan salah satu pola yang diupayakan bisa menjadi solusi terhadap tantangan tersebut. Pendidikan Jarak Jauh di Indonesia bukan menjadi pendidikan alternatif, tetapi telah menjadi sub-sistem pendidikan nasional di Indonesia Berikut kerangka umum PJJ dalam perspektif sistem.

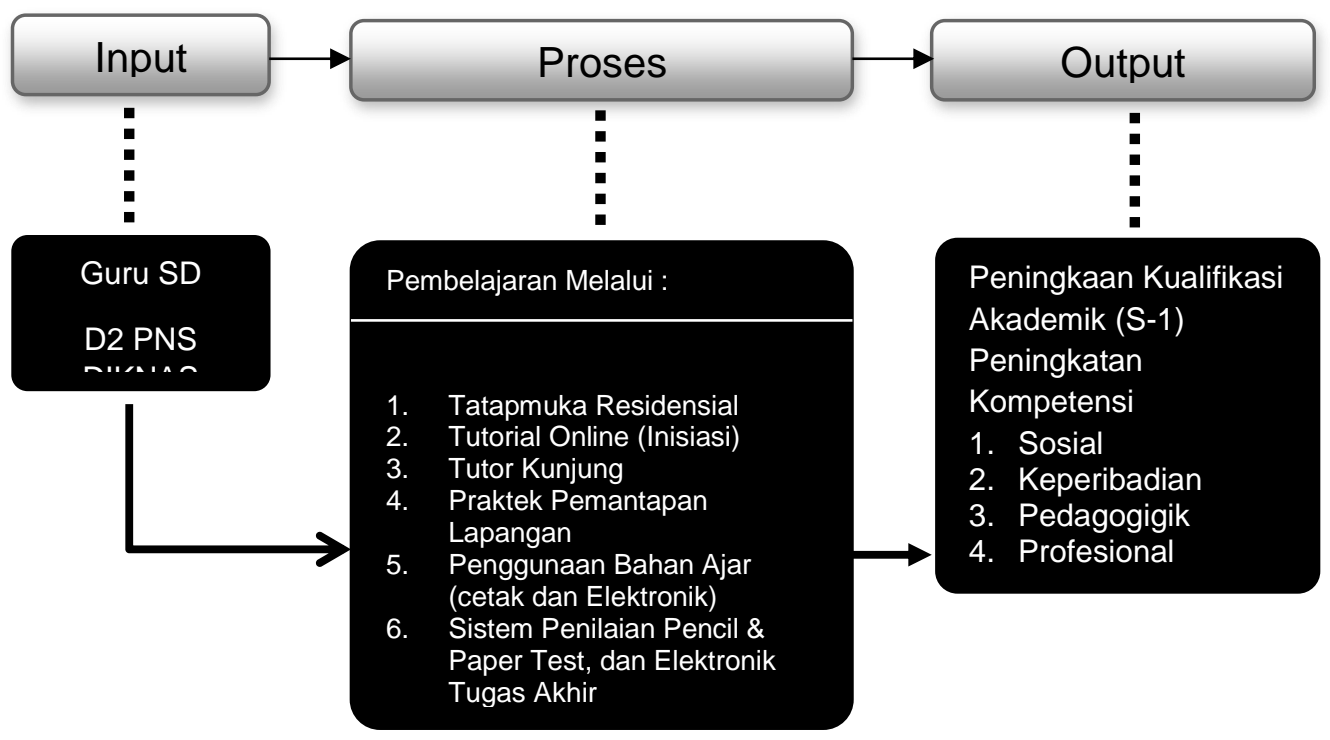

Bagan 1 : Sistem PJJ PGSD

Input sistem ini adalah guru SD yang belum berkualifikasi S-1 yang telah menjadi guru. Proses seleksi mahasiswa dilakukan secara selektif kerjasama antara lembaga penyelenggara dengan Dinas Pendidikan Kota/Kabupaten, dengan mengacu pada kriteria yang ditetapkan oleh UT dengan standar Dikti.

Model Proses Pembelajaran, Sesuai dengan karakteristik model blended elearning yang digunakan pada PJJ PGSD UT, yakni memadukan pembelajaran tatap muka, dengan tutorial online serta penggunaan berbagai bahan ajar, maka proses pembelajaran pada model ini dapat digambarkan sebagai berikut : 


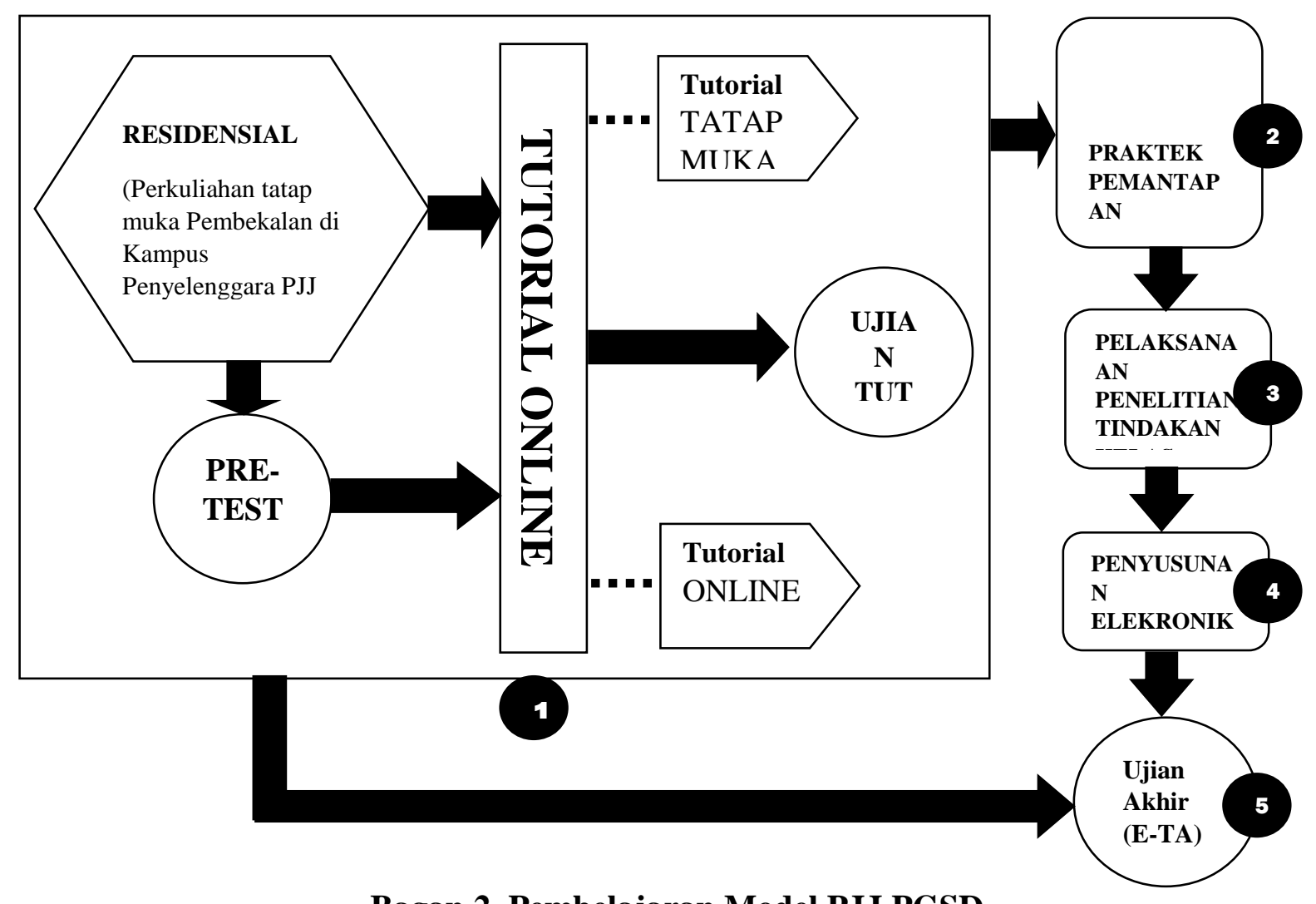

Bagan 2. Pembelajaran Model PJJ PGSD

Proses pembelajaran pada perkuliahan PJJ dapat diuraikan sebagai berikut :

\section{a. Residensial}

Kegiatan residensial yaitu kegiatan tutorial tatap muka (face to face) antara Tutor dengan mahasiswa yang dilakukan di kampus penyelenggara. Selama beberapa minggu mahasiswa dari daerah difasilitasi dengan disediakan penginapan untuk diberikan perkuliahan pengantar sebelum mereka mengikuti perkuliahan online di daerahnya masingmasing. Proses pembelajaran selama residensial disesuaikan dengan sistem pembelajaran reguler, misalnya pengaturan waktu satu SKS yakni 45 menit dan $1 \mathrm{X}$ pertemuan untuk 2 SKS sebanyak 90 menit.

b. Kegiatan Tutorial
Kegiatan tutorial secara umum dilakukan dengan dua cara, yaitu tutorial online dan tutorial kunjung dengan tatap muka. Menurut Surat Keputusan Menteri Diknas tahun 107 tahun 2001 tentang Penyelenggaraan Program Pendidikan Tinggi Jarak Jauh definisi tutorial adalah bentuk bantuan belajar akademik yang secara langsung berkaitan dengan materi ajar, dan dapat dilaksanakan secara tatap muka maupun jarak jauh

\section{c. Praktek Pengalaman Lapangan}

Sesuai dengan struktur kurikulum yang telah ditentukan Dikti, terdapat kegiatan Praktek Pengalaman Lapangan (PPL), yaitu kegiatan untuk lebih mengasah keterampilan mengajar mahasiswa. Pemantapan Praktik Lapangan (PPL) 
merupakan salah satu matakuliah kulminatif pada Program PJJ S1PGSD yang membekali mahasiswa dalam ketrampilan menyusun RPP (skenario perbaikan pembelajaran) sebagai suatu rencana pemecahan masalah pembelajaran, melakukan praktik pembelajaran yang sesuai dengan RPP, ketrampilan mengobservasi pembelajaran dan melakukan refleksi serta menyusun laporannya.

\section{d. Kegiatan Penelitian Tindakan Kelas}

Kegiatan ini merupakan akumulasi dari seluruh rangkaian kegiatan perkuliahan PJJ PGSD dan merupakan kegiatan puncak. Kegiatan ini bertujuan untuk mengasah profesionalisme guru melalui kegiatan penelitian untuk mengatasi permasalahan-permasalahan pembelajaran. Kegiatan ini dilakukan pada semester akhir. Tempat pelaksanannya adalah di sekolah tempat mahasiswa bertugas. Produk dari penelitian ini tidak disusun dalam bentuk skripsi (printed), akan tetapi dikemas dalam bentuk Elektronik tugas akhir atau E-TA.

\section{e. Penyusunan Elektronik Tugas Akhir}

\section{KESIMPULAN}

Kesimpulan umum dari penelitian ini bahwa diperlukannya perangkat pembelajaran untuk meningkatkan modus tutorial pada Mata Kuliah Peneitian Tindakan Kelas (PTK) melalui pemanfaatan ICT dalam bentuk Model Blended Learning, yakni model pembelajaran yang mengkombinasikan antara pertemuan tutorial tatap muka dengan belajar mandiri melalui online learning dan pemanfaatan sumber belajar lainnya seperti printed materials dan audio-visual materials. Tujuan model ini adalah meningkatkan akses pada sumber
E-Tugas Akhir (e-TA) merupakan salah satu mata kuliahpada program PJJ S-1 PGSD yang berbobot 4 SKS. e-TAyang diberikan kepada mahasiswa diharapkan dapatmencerminkan sosok utuh kompetensi guru SD/MI, yangdikelompokkan ke dalam empat rumpun kompetensi.

\section{f. Ujian Akhir E-TA}

Ujian akhir perkuliahan PJJ PGSD diserahkan sepenuhnya kepada LPTK penyelenggara. Dalam hal ini Dikti tidak mewajibkan LPTK untuk melakukan pengujian secara langsung (ujian sidang), namun yang pasti harus di uji adalah produk berupa elektronik portofolio siswa. Beberapa universitas seperti halnya UPI melakukan pengujian secara langsung, yakni mahasiswa diuji untuk dapat mengoperasikan dan mempresentasikan produk akhirnya dihadapan penguji. Hal ini untuk memberikan kesan mendalam kepada mahasiswa dan memberikan pengalaman berharga. Selain itu objektivitas penelitian dapat diuji secara akurat, karena ada klarifikasi langsung oleh mahasiswa kepada tim penguji.

pembelajaran, meningkatkan kemandirian dan mutu perkuliahan.

Secara khusus, kesimpulan dalam penelitian ini dapat diuraikan sbb :

1. Kondisi kondisi pembelajaran saat ini pada Mata Kuliah Penelitian Tindakan Kelas (PTK) pada Sistem Pembelajaran Jarak Jauh program S1 PGSD diwilayah kerja UPBJJ UT Bandung menggunakan sistem tutorial. Dalam satu semester mahasiswa bertemu dengan tutor di Pokjar sebanyak delapan kali pertemuan tatap muka. Mahasiswa belajar selain dengan tutor juga dilengkapi dengan 
modul cetak yang disiapkan oleh UT pusat.

2. Bentuk Rencana Pelaksanaan Pembelajaran pada Sistem Pembelajaran Jarak Jauh yang digunakan saat ini pada program S1 PGSD UPBJJ UT Bandung menggunakan dua format, yaitu (1) Rancangan Aktivitas Tutorial (RAT), dan (2) Satuan Aktivitas Tutorial (SAT). RAT disiapkan untuk semua pertemuan (8X) memuat butir-bukir tujuan, materi pokok, aktivitas dan sistem evaluasi selama tutorial berlangsung. SAT berisi identitas mata kuliah, tujuan, materi pokok, aktivitas mahasiswa dan tutor, serta evaluasi pembelajaran untuk satu pertemuan tutorial.

3. Bahan ajar pada Sistem Pembelajaran Jarak Jauh yang digunakan saat ini pada program S1 PGSD diwilayah kerja UPBJJ UT Bandung menggunakan modul cetak yang disiapkan oleh UT Pusat. Setiap mahasiswa diwajibkan untuk memiliki modul tersebut, karena komponen utama sebagai bahan belajar mahasiswa selama tutorial.

4. Metode pembelajaran yang digunakan pada Sistem Pembelajaran Jarak Jauh yang digunakan saat ini pada program $\mathrm{S} 1$ PGSD diwilayah kerja UPBJJ UT Bandung lebih banyak mengkombinasikan antara presentasi oleh tutor, diskusi kelas dan penyajian oleh mahasiswa. Kegiatan diskusi sebagai metode yang paling sering digunakan sebagai sarana kolaborasi, kerjasama diantara mahasiswa untuk memecahkan permasalahan pembelajaran. Selain itu tutor memberikan penugasan (resitasi) kepada mahasiswa untuk melatih kemandirian belajar. Latihan yang diberikan diantaranya proses penyusunan proposal PTK.

5. Respon Tutor dan pengelola terhadap Penerapan Model Blended Learning pada Sistem Pembelajaran Jarak Jauh di Universitas Terbuka diwilayah kerja UPBJJ Bandung. Seluruh Tutor (100\%) menyatakan perlunya pengayaan tambahan dari pola tutorial yang ada saat ini untuk meningkatkan mutu perkuliahan PTK. Tutor mengharapkan bahwa perkuliahan tutorial PTK lebih banyak praktek penyusunan dan pelaksanaan PTK. Hal tersebut dinyatakan oleh setengah dari responden $(50 \%)$ menyatakan ingin "lebih banyak praktek penyusunan dan pelaksanaa PTK.

Rancangan Model Blended Learning pada Sistem Pembelajaran Jarak Jauh di Universitas Terbuka diwilayah kerja UPBJJ Bandung. Kerangka umum sistem PJJ yang dikembangkan di Indonesia secara sistemik dapat dilihat dari perspektif pendekatan sistem, yakni meliputi input, proses dan output, termasuk didalamnya instrumental input dan environmental input. Instrumental input berkaitan dengan kebijakan-kebijakan yang melandasi penyelenggaraan program yang diatur oleh pemerintah.

\section{DAFTAR PUSTAKA}

Baggaley, J. and T. Belawati. (2007). Distance education technology in Asia. Part 1: Past and present. Lahore: Virtual University of Pakistan.

Belawati, T. (2003). The implementation of e-learning in Indonesian distance education. In D. Andriani (Ed.), Cakrawala Pendidikan: E-learning dalam Pendidikan. Jakarta: Universitas Terbuka.

Bloom, B. S. (1956). Taxonomy of educational objectives: The classification of educational goals. New York: Longman.

Bonk, C. J., \& Graham, C. R. (2006). The handbook of blended learning: Global 
perspectives, local designs. San Francisco, CA: Pfeiffer Publishing.

Darling-Hammond. dan Bransford (Ed.).2005. Preparing Teachers for $a$ Changing World. San Francisco: Jossey-Bass Publishing.

Govindasamy, T. (2002). Successful Implementation of e-Learning: Pedagogical Considerations. Internet and Higher Education, 4, 287-299.

Hammer, M., dan Champy, J. (1993). Reengineering the Corporation: A Manifesto for Business Revolution. New York: HarperBusiness.

Harry B.Santoso (2004). E-Learning; Belajar Kapan Saja dan Dimana Saja.

Harding, A., Engelbrecht, J., Lazenby, K. and le Roux, I. (2005) Blended learning in mathematics: Flexibility and Taxonomy in Handbook of Blended Learning Environments: Global Perspectives, Local Designs. Editors: Curt Bonk and Charles Graham, Pfeiffer Publishing.

Hasibuan, M. S., \& Hasibuan, Z. A. (2006). Preliminary Report Overview on ELearning System. In Seminar Nasional Aplikasi Teknologi Informasi (SNATI).

Lie, A. (2004). Pendidikan dalam Dinamika Globalisasi. Dalam Widiatono, T. D. Pendidikan Manusia Indonesia. Jakarta: Kompas dan Yayasan Toyota dan Astra, 217-231.

Loughran, John. 2010 . What Expert Teachers Do; Enhancing professional knowledge for classroom practice. Crows Nest NSW, Australia: Allen\&Unwin.

Sukmadinata, Nana Syaodih (2005). Metode Penelitian Pendidikan.Rosdakarya. Bandung
Mohandas, R. (2003). ICT and e-Learning in Indonesia. Presentasi di Tainan, Taiwan, 25-27 Maret.Negroponte, N. (1998). Being Digital. Terjemahan, Bandung: Mizan.

Pannen, P. (2005). Pemanfaatan ICT dalam Pembelajaran. Presentasi pada Seminar Sun Commitment in Education and Research Industry, Jakarta, 29 Juni.

Paurelle, S. (2003). E-learning and constructivism. Learning and Teaching Enhancement Unit (LTEU). Canterbury Christ Church University College. Briefing paper.

Pituch, K. A., dan Lee, Y.-k. (2004). The Influence of System Characteristics on e-Learning Use. Computers \& Education.

Purwanto. (2009). Evaluasi Hasil Belajar. Yogyakarta: Pustaka Pelajar

Hadjerrouit, Said (2007) Applying a System Development Approach to Translate Educational Requirements into ELearning. Agder University College, Kristiansand, Norway.

Wall, J., \& Ahmed, V. (2008). Lessons learned from a case study in deploying blended learning continuing professional development. Engineering, Construction and Architectural Management, 15(2), 185202.

Zhao, J. (2008). An examination of students' perception of blended e-learning in Chinese higher education. Technologies for E-Learning and Digital Entertainment, 162-170. 